\title{
"A question of power and war:" Social Conflict in Hamburg and London in the Late Nineteenth Century ${ }^{1}$
}

\author{
Christine Krüger and Friedrich Lenger
}

It is stating the obvious if one stresses the intimate relationship between questions of security and those of power. The problem becomes more interesting, however, if one contrasts different conceptions of both power and security and their implications for empirical analysis. This is what this article tries to do, taking the reactions to social unrest in Hamburg and London at the end of the nineteenth century as the empirical example and the conceptual work of the Copenhagen School of security studies and the theoretical offerings of governmentality studies in a Foucauldian tradition as analytical tools. ${ }^{2}$ For London, we will concentrate particularly on three events: the West End Riots in February 1886, "Bloody Sunday" in November 1887 and the dock labourers' strike in summer 1889, and for Hamburg on the riots of May 1890 and the dock workers' strike of 1896/97. ${ }^{3}$ And since comparing two cases and two theoretical approaches at the same time is bound to confuse the reader, the main part of the article will demonstrate the usefulness of the terms 'securitization' and 'desecuritization' ${ }^{4}$ for understanding our two metropolitan stories, while the comparative reflection of the tradition of governmentality studies will be reserved for a much briefer epilogue.

1 The contributions of the two co-authors are very unequal: while Christine Krüger has undertaken all the empirical work and written most of the text, Friedrich Lenger has concentrated mostly on the epilogue at the end. We are grateful to Sebastian Haus for his helpful commentary on an earlier version of this article.

2 For a comparative evaluation of both traditions cf. Opitz 2008.

3 Cf. for the Trafalgar Square Demonstrations and for "Bloody Sunday" Keller 2008; for the London strike McCarthy 1889; Wasp/Davis 1974; for Hamburg Grüttner 1984.

4 We define desecuritization as the process in the course of which issues or developments that have been securitized before cease to be regarded as a security problem. See Hansen 2012, pp. 542-544. 
In accordance with Critical Security Studies and particularly the Copenhagen School of Securitization, ${ }^{5}$ we do not understand security in a normative way but rather ask how contemporaries defined security, how they securitized specific phenomena (i.e. how they identified and created security issues), and how definitions of security have changed over time. However, even if concepts of security and of how security should be guaranteed were liable to historical change, one could say that they were always inseparably linked with feelings of insecurity (i.e. with the perception of existential threats).

The aim is to analyze the relationship between security discourses and security practices on the one hand and power relations on the other: We ask in what situations security arguments gained or lost persuasive power. Who had recourse to securitization and what kind of power relations provided the conditions for it? What other instruments of power competed with it? And how did securitization either change or stabilize the balance of power?

Although the perception and discussion of social conflict as a security problem were very similar in Hamburg and London, security discourses and practices were much more influential in Hamburg than in London. This makes the comparison of both cities useful for our analysis. The causes for the differences provide answers to the question of how securitization and power were interrelated. Moreover, with different conceptions of security competing in both cities, the comparison helps us to understand why some of them prevailed while others failed.

In the first three parts of this article, we will explore three distinct security discourses, which can be attributed to three socio-political camps and can be found in both cities. The first two of these camps are formed by the middle classes. The camp that could be denominated as the 'camp of confrontation' and the camp of liberal social reform that could also be defined as 'camp of dialogue', while the third camp is that of organised labour. In the fourth and last part, we will study the security policies pursued by the state and especially by the police forces in both cities. Sources include various newspapers of different political colours, writings of social reformers and social scientists, as well as archival material, especially from the London Metropolitan Police and the Police Department of the city of Hamburg.

5 For a short introduction cf. C.A.S.E. Collective 2006; Wæver 1995, pp. 46-86. 


\section{The camp of confrontation}

Like all over Europe, the middle classes in London and Hamburg discussed intensively whether and under which circumstances class conflict could become a danger for the city or for the nation. This question was closely connected to their perception of an imminent transformation of the societal distribution of power. Two distinct positions can be clearly discerned. On the one hand, there were those who could be described as the 'camp of confrontation', comprising conservatives as well as some liberals - on the German side, especially many national liberals. Supporters of this camp consistently endeavoured to securitize the labour movement. On the other hand, there was the 'camp of dialogue', the adherents of which promoted social reform. This camp particularly included supporters of the Radical Party in London, the so-called 'Kathedersozialisten' in Hamburg. Contrary to the camp of confrontation, supporters of the 'camp of dialogue' often tried to rather desecuritize social conflict. It is worthwhile to have a closer look at both sides. We will start with the adherents of the camp of confrontation, for whom security was a most prominent issue.

In London as well as in Hamburg, new evidence of social unrest in the last decades of the nineteenth century gave conservatives occasion to call for a larger and more powerful police force and for new and more restrictive laws. This call for more security generally referred to the threat that the middle and upper classes perceived in face of the growing power of the organized working classes. The exact way this menace was defined differed according to the situation. After the pillage of the luxury boutiques of London's West End in February 1886, for example, the affected shopkeepers highlighted the damage to their property and blamed the Metropolitan Police for not having been able to prevent the rioting. ${ }^{6}$ Similarly, in October and November 1887, when Trafalgar Square became the stage for huge protest meetings of unemployed labourers, hotel owners and traders lamenting the economic loss these demonstrations had caused requested police protection. ${ }^{7}$

However, with the aim to stabilize the traditional power structure, calls for security tended to assume dimensions that surpassed the urban context.

6 The National Archives, HO 144/165/A42380; Thomas Goode: To the editor of The Times, in The Times, 9 February 1886, p. 6.

7 The Unemployed in London, in Illustrated London News, 29 October 1887, p. 504; The Defence of Trafalgarsquare, in The Times, 14 October 1887, p. 6. 
For instance, anti-socialist journalists did not restrict themselves to portray the dock strikes as an economic disaster for both cities, but rather described them as a danger for the social order (i.e. a danger that concerned not only the city but also the nation as a whole). In 1889, the London dock directors stressed that the dock labourers' strike was not a wage dispute but a power struggle. ${ }^{8}$ By this they tried to strengthen their claim for more police protection of strike breakers. With even more emphasis, the Hamburg employers put forward the same argument to justify their refusal of an offer for an arbitrational settlement of the strike in 1896/97. ${ }^{9}$

Moreover, in both cities the entrepreneurs and their supporters depicted the walkouts as declarations of social war by international social democracy. The London dock directors believed that "the strike was finally determined upon by the Socialistic section of a Labour Congress held in Switzerland a few weeks previously". ${ }^{10}$ And a journalist of The Globe and Traveller was convinced that there were "persons who would wish nothing better than, for ulterior ends, to see London in a state of darkness and famine. Such things have been literally threatened, as incidents in a general war." For him, the strike was "but part and parcel of an organized campaign of labour against the capital."11 With such claims, the dock companies and the employer-oriented press supported their call for a stronger police intervention in the strike. Similarly in Hamburg, the entrepreneurs alleged that the International Federation of Ship, Dock and Riverside Workers, founded a few months earlier in London, had instigated the strike. Whereas the simpler variant of this theory blamed the English union leaders to have persuaded the Hamburg workmen to strike, a more complex variant saw British dock companies as the culprits, who, in order to damage their German competitors, had bribed the English union leaders to drive their German comrades into the strike. ${ }^{12}$ This conspiracy theory

8 The Globe and Traveller, 24 August 1889, p.3.

9 Der Strike, in Hamburger Nachrichten, 28 November 1896, Morgen-Ausgabe, erste Beilage; Zum Streik der Hafenarbeiter. Die Antwort des Arbeitgeberverbandes an Herrn Senator Dr. Hachmann, in Der Hamburgische Correspondent, 3 December 1896, Morgen-Ausgabe, p. 11.

10 M.C. Norwood: Report on the late labour strike, 3 October 1889, The National Archives, MEPO 2/226.

11 The Strike, in The Globe and Traveller, 26 August 1889, p. 4.

12 Zum Streik der Hafenarbeiter, in Der Hamburgische Correspondent, 29 November 1896, Mittags-Ausgabe, p. 2; Englische Brandstiftungen, in Hamburger Nachrich- 
made the alleged danger appear more sinister and the call for security measures more urgent.

Such an interpretation securitized the strikes, claiming that they were no longer private affairs between entrepreneurs and workers, but existential threats to society. Whereas the question whether the state had the right or the duty to intervene into labour conflicts remained controversial among entrepreneurs, according to their interpretation as existential threats, strikes turned into public issues to which the state was supposed to react. And the greater the danger, the more drastic the measures against strikers could be demanded. Thus, the Hamburg ship owners and their supporters considered the proposal to convene an arbitration tribunal in order to settle the strike as inappropriate or even dangerous. Instead, periodicals that took side with the entrepreneurs advocated a renewal of Bismarck's anti-socialist laws. For instance, the conservative Hamburger Nachrichten claimed, "If our laws are not sufficient to protect us, we need to create new laws in the greatest hurry, in order to be able to oppose the enemy of our welfare." 13

In the camp of confrontation, security was a frequently debated issue that enjoyed high priority in the discussion of social conflict. All in all, the line of argument was similar in both cities. However, while security discourse prevailed in Hamburg, where it was shared by conservatives and national liberals alike, it was less dominant in London. For example, the interpretation of the dock strike as a socialist attempt to overthrow the social order-i.e. as a security threat-was not able to assert itself in the British metropolis. The advocates of social reform constituted a much stronger counterweight to the camp of confrontation than they did in Hamburg.

\section{The camp of dialogue}

Compared to the camp of confrontation, the social reformers referred relatively seldom to security. Moreover, their security discourses diverged notably. The most obvious difference was that the social reformers preferred

ten, 1 December 1896, Morgen-Ausgabe, p. 1; Lokales. Zum Streik der Hafenarbeiter, in Börsenhalle, 1 December 1896, Nachmittags-Ausgabe.

13 Die Tyrannei einer kleinen Majorität, in Hamburger Nachrichten, 25 December 1896, Morgen-Ausgabe. 
other strategies for handling social conflict. For example, during the Hamburg strike, an article in the left-liberal Kieler Neueste Nachrichten stressed that the period was "so much on the move and in danger socially and economically that the aim should be to mitigate and reconcile the clashing interests, instead of aggravating them." 14 The author was convinced that this was the only way to "take the most dangerous and violently revolutionary edge off the social movement." Social reformers relied on dialogue and conciliation rather than on showdown and combat. Even if, as we could see here, some social reformers warned that fierce suppression would lead to a radicalization of the working classes, in sum, they did not so much fear the working class itself as the escalation of social antagonism. And the threat of escalation was a distant one; it was not an immediate one, pressing for securitization.

The British settlement movement best represents the ideals of the camp of dialogue. Toynbee Hall, as well as other settlements, acted out of the conviction that one of the reasons for the disruption of social peace was the increasing urban segregation of rich and poor city districts. ${ }^{15}$ Inviting Oxbridge graduates to live for some time in metropolitan slums, the settlement houses pursued the target to promote mutual knowledge and understanding between classes. Social scientists shared these convictions. The social researcher Charles Booth, for example, took the motivation for his seminal study Life and Labour of the People of London from the desire to gain deeper knowledge about the London poor. ${ }^{16}$

In Hamburg, too, social reformers believed that dialogue with and better understanding of the working classes could help to overcome social disruption. For instance, the sociologist Ferdinand Tönnies recommended studying the living conditions of the urban working classes on an impartial scientific basis in order to avoid an exacerbation of social conflict. As a sociologist, he felt compelled to interfere with the Hamburg dock strike, sharply criticizing the dock directors' intransigent position and their will to "be and remain the masters." 17 Like many social reformers, he advocated as a matter of principle the settlement of labour conflicts by arbitration. The Hamburg dock strike appeared all the more significant to him because he believed that it had turned into a dispute about "the fundamental

14 Bildung und Arbeit, in Kieler Neueste Nachrichten, 30 January 1897.

15 Briggs/Macarntey 1984; Meacham 1987.

16 Booth $1902 \mathrm{f}$.

17 Tönnies 2010a, p. 224. 
question whether such conflicts should be fought out until the submission of one party or whether they should be terminated by arbitrational activity." 18 In his writings and in two speeches at strike assemblies, Tönnies propagated the building-up of strong trade unions, as these would enable the labourers to negotiate. ${ }^{19}$ In January 1897, he and some other professors and clergymen tried to help the strikers with an appeal for donations. The aim was, "for the sake of the idea", to create the conditions that would enable "the one side as well as the other to lead the negotiations without the pressure of imminent misery." 20 With the appeal for donations and for a peaceful settlement of the labour dispute, the group of professors and clergymen tried to work against the widening of the social power gap, which they considered as harmful.

Advocating dialogue and negotiations, many adherents of liberal social reform rejected the securitization of the working classes. Tönnies, for example, condemned that the entrepreneurs and their supporters forecasted doomsday scenarios for political purposes. "The interpretation of social conflicts is still left to the interested parties, i.e. the political troglodytes, who produce artificial lightning and thunder, in order to make believe that a thunderstorm had broken out," he deplored, convinced that from an "unbiased viewpoint the issue did not really appear very dangerous." 21 Similar attempts to desecuritize the urban social conflict are found on the British side. A famous example is the often-cited appraisal of slum life in the introductory chapter of Booth's inquiry: "The hordes of barbarians of whom we have heard, who, issuing from their slums, will one day overwhelm modern civilization, do not exist. There are barbarians, but they are a handful, a small and decreasing percentage: a disgrace but not a danger." 22

Like Booth, many social reformers preferred to evoke other values, such as justice, honour, and moral or Christian obligations in order to justify their call for social reforms. During the London dock strike, for instance, Lloyd's Weekly Newspaper praised the strikers, who had "with

18 Berliner Börsenzeitung, 22 January 1896, p. 3; for the social reformers' commitment to arbitrational settlement of labour conflicts, cf. Reulecke 1981; vom Bruch 1981.

19 Tönnies 2010b, p. 156; Tönnies 2010a, p. 222.

20 Berliner Börsenzeitung, 22 January 1896, p. 3.

21 Tönnies, 2010b, p. 100, p. 157.

22 Booth 1902, vol. 1.1, p. 39. 
manly dignity asserted the rights of labour to fair remuneration." ${ }^{23}$ Liberal London newspapers also greatly emphasized human rights or, as they put it, the "right to live." 24 Reynold's Newspaper maintained: "The question between capital and labour for the future is to be stated in this way: How much payment suffices for decent livelihood." 25 And in overt opposition to the entrepreneurs' interpretation of the strike, the same paper argued: "The great strike is not a conspiracy of idealists, but a combination of earnest men in defence of the simple right to live in a condition that may make life tolerable." 26

Although such an emphasis on the entitlement to wages allowing a minimum standard of living was more prominent on the British side, the viewpoints of social reform were quite similar in the two cities. On the whole, however, the social reform camp was much weaker in Hamburg. The reaction to the appeal for donations by the social reformers clearly illustrates this. All middle-class Hamburg newspapers harshly criticized this intervention into the labour conflict. Moreover, the conservative and national liberal press portrayed not only the labour movement but also its middleclass supporters as a danger to the social order. Securitization is often part of the construction of the 'enemy' and serves as a vehicle for inclusion and exclusion. Accordingly, the recommendation of the Hamburger Nachrichten as to sanctions against the authors of the appeal for donations was as follows: "Although the social question is, as the Hamburg strike proves once again, a question of power and war, unfortunately martial law cannot be applied to such actions. But the mildest punishment, which has to be imposed by the bourgeois society itself, as long as there is no anti-socialist law, is exclusion." ${ }^{27}$ Moreover, the conservative and national liberal press demanded to implement censorship measures for university lecturers. ${ }^{28}$ This suggestion was not followed up. Yet the authors of the appeal for donations were sanctioned. They were prosecuted for illegal fundraising, and the University of Kiel summoned two of its professors who were among

23 The Strike Settled, in Lloyd's Weekly, 15 September 1889, p. 1.

24 Justice for Dock Workers, in Lloyd's Weekly, 1 September 1889, p. 1.

25 The Democratic World, in Reynold's Newspaper, 1 September 1889, p. 3.

26 Special Notes, in Reynold's Newspaper, 25 September 1889, p. 8.

27 Hamburg, 26. Januar, in Hamburger Nachrichten, 26 January 1897, Abend-Ausgabe.

28 Der Professoren-Socialismus, in Hamburger Nachrichten, 25 January 1897, Abend-Ausgabe. 
the signatories of the appeal and urged them to justify themselves. ${ }^{29}$ As for Tönnies, his support of the strikers brought him into the disrepute of being a social democrat and affected his scholarly career. For years to come, he had difficulty getting a full professorship. ${ }^{30}$ And professor of economics Heinrich Herkner, feeling politically and professionally ostracized in the Germen Empire after having signed the appeal of support for the strikers, moved to Switzerland in $1898 .{ }^{31}$

In London, by contrast, the advocates of social reform found much more acceptance and were able to shape social policy to a considerable degree. They were also far from falling into disrepute. For example, during the London strike, settlement residents helped the strikers to organize the strike pay. ${ }^{32}$ After the strike's end, Samuel Barnett, the founder and Warden of Toynbee Hall, invited the strike leaders "to celebrate the victory" with a "supper party." ${ }^{33}$ However, taking the working classes' side did not tarnish Barnett's reputation. The high respect shown towards the commitment of the social reformers enabled them to take on an intermediary role and thus constituted one of the conditions for the successful settlement of the London strike by arbitration.

In order to explain why the Hamburg entrepreneurs' efforts to securitize the labour conflict were successful, two points need to be considered. First, the Hamburg employers had a very important position in Hamburg and could use their close personal connections to members of the Senate for numerous meetings and face-to-face negotiations with leading decision makers. ${ }^{34}$ Besides, they definitely had a strong influence over the Hamburg middle-class press, although the surviving sources give no evidence that they exerted any direct pressure on journalists or editors, as the social democratic newspaper Das Hamburger Echo suspected. ${ }^{35}$ The second and probably more important reason was that the Hamburg entrepreneurs and their supporters were in accord with a wide spread anti-socialist feeling

29 Hamburg, 26. März, in Neue Hamburger Zeitung, 26 March 1897, p. 1; Tages-Uebersicht, in General-Anzeiger für Hamburg-Altona, 12 February 1897, p. 1.

30 Cf. Tönnies/Paulsen 1961, pp. 330-332.

31 Herkner 1924, pp. 97-99.

32 Toynbee Record, vol. 2, no. 1, October 1889, pp. 7-10; vol. 2, no. 2, November 1889, p. 20.

33 Pall Mall Gazette, 23 September 1889.

34 Evans 1987, pp. 1-50; Hamburger Staatsarchiv 111-1 Cl XI Gen No. 2. Vol 74 Fasc $1 b$.

35 Das Hamburger Echo, 7 January 1897. 
and a strong tradition of securitization of the working classes that had resulted in Bismarck's anti-socialist laws and exacerbated the class conflict in the German Empire.

In London, the political field was quite different. Liberal attitudes had more impact in England generally, while the labour movement was weaker than in Germany. Contrary to Germany, the middle class did not believe that a socialist revolution was an imminent danger, and consequently a cooperation between liberals and working class organisations was not scandalized in the same way as it was in Germany.

\section{The organized working classes}

When the middle classes raised the topic of urban security, the potential dangerousness of the labour movement was at the centre of controversy. The organized labour classes themselves inevitably had to take a stand on this issue. Their discourse remained most ambivalent in both cities. On the one hand, working class and social democratic organisations had an interest in demonstrating their power and threatening revolution. For instance, agitators regarded it as one of the main purposes of the mass processions of the unemployed or of socialist 'monster meetings' in 1886 and 1887 that the sheer number of protesters should impress and intimidate the London middle classes. In this vein, Henry Hyndman addressed himself to the labourers at a socialist meeting only three weeks after the Trafalgar Square riots: "It was by combination that they would be able to put such fear into the hearts of the governing classes that they would no longer refrain from taking the case of the masses into account." ${ }^{36}$ Thus, being securitized gave power to the labour movement.

On the other hand, the spokespersons of organised labour were eager to desecuritize the working classes. After the London West End riots as well as following the Hamburg riots of 1890 or the two days of rioting in the aftermath of the Hamburg dock strike, socialists and working class organizations emphasized that no honest workman was to blame for violence, demolition and spoliation, but that "mischievous youths," "professional

36 Monster Socialist Meeting in Hyde Park, in Reynolds Newspaper, 28 February 1886, p. 1. 
thieves" or "roughs and rowdies"-who "could not claim to call themselves labourers" - had committed the offences. ${ }^{37}$

This ambivalent security discourse is due to the aim of the workingclass organisations to redefine the tasks of the state. Again, this can be explained by the fact that the guarantee of security was traditionally one of the state's reasons for being, while it was not yet a common conviction that the guarantee of social welfare and social justice belonged to the scope of state duties. Thus, the menace of revolution could advance social reform. However, threatening social upheaval was a double-edged strategy, as the state's security policy tended to be police repression instead of social reform. To some extent, this might explain why socialist leaders often stressed the fact that time was not yet ripe for revolution. ${ }^{38}$ By this they implied that the dangers of a more distant future might be prevented by timely reforms.

While the labour movement became an object of securitization, it was hardly able to use securitization as an instrument of empowerment for its own purposes. This is clearly demonstrated by the example of the Hamburg dock strikes. If the strikers wanted to be victorious, they had to succeed in two respects. Firstly, they had to impede the employers from recruiting blacklegs on a large scale. This was particularly difficult for the dock labourers who, being unskilled, could easily be replaced. Therefore, strikers repeatedly tried to intimidate strike breakers by menacing them or even by using physical violence. ${ }^{39}$ However, deterring blacklegs was only one condition for winning the strike. The second condition was to provide sufficient funds in order to guarantee the strike pay for an unforeseeable duration. As union membership had been low before the strikers laid down work, they depended on affluent sympathizers (i.e. they needed the goodwill at least of parts of the "Bürgertum"). This meant that they had to refrain from physical violence as an instrument of power. This explains why, in the working class press and at the strikers' assemblies, labour leaders

37 The Rioting in London, in Reynolds Newspaper, 14 February 1886, p. 4; The Riots in the West-End, in Pall Mall Gazette, 9 February 1886, p. 9; Eine regelrechte Revolte, in Das Hamburger Echo, 14 May 1890; cf. Grüttner 1984, p. 145f.; more generally for this kind of argumentation, cf. Lindenberger 1993.

38 Special Notes, in Reynolds Newspaper, 25 August 1889, p. 8.

39 Hamburger Staatsarchiv, 331-3/7138. 
repeatedly urged their audience, to prove their discipline and not to lapse into violence. ${ }^{40}$

The ambivalence inherent in the conditions for settling the labour dispute with the desired outcome permeated the whole walkout. While on the one hand the strike leaders recommended to renounce violence, on the other hand they permitted to read out the names of blacklegs, well aware that this was an invitation for applying sanctions that could easily end in violence. ${ }^{41}$ Another illustration of the conflicting strategies of the strikers may be found in the conversation of some dock labourers that was recorded by a police spy, who had shadowed a working class pub. ${ }^{42}$ In this conversation, one of the strikers described his encounter with two blacklegs. He had tried verbally to convince them to lay down their work, but without success. Thereupon, "[I]t would not have taken much," he admitted, "and he had slapped them into the face." Another striker admonished him not to resort to violence. Otherwise they would lose "the sympathy of the public," and thus harm their own interests. A third interlocutor affirmed, believing that the employers were only waiting for an escalation of violence. He preferred to stigmatize the blacklegs, for example, by publishing their names in the newspaper.

The strikers had few instruments of power in order to deter the strike breakers. Therefore, violence could serve as a last resort. However, the lack of financial means also kept them in a dependency that proscribed violence. Therefore, strikers also tried to make use of securitization as an alternative way to exercise power against blacklegs and entrepreneurs. Again and again, they blamed the dock directors for endangering the city by using foreigners as strike-breakers. In fact, already in the very first days of the walkout, the employers had threatened to hire thousands of Italian workers. ${ }^{43}$ Although this particular threat was not carried out, they were soon able to recruit two or three thousand new labourers, many of whom came from abroad. ${ }^{44}$ During the strike assemblies and in the social-

40 E.g. Bericht über Öffentliche Versammlung der am Petersen-Kai beschäftigten Arbeiter, 28 November 1896, Hamburger Staatsarchiv, 331-3/7095.

41 Polizei-Offiziant Burow, Bericht über die öffentliche Versammlung der Getreidearbeiter und Schiffsmaler, 24 January 1897, Hamburger Staatsarchiv, 331-1/7123.

42 Polizei-Offiziant Graumann, Vigilanz-Bericht, 7 December 1896, Hamburger Staatsarchiv, 331-1/7122.

43 G. H. Blohm: Zum Strike der Schauerleute, in Hamburger Fremdenblatt, 24 November 1896.

44 Hamburger Staatsarchiv 331-3/7119; 331-3/1723; cf. Bieber p. 125. 
ist press, the alleged great dangers of this immigration were a big issue. The strikers were convinced that the hygienic, moral and educational standards - especially of the Polish, Italian, African and Asian immigrantswere inferior to their own. They believed that the influx of foreign workers into Hamburg would not only exacerbate the problem of unemployment but also increase the crime rate. ${ }^{45}$ Yet an even more serious warning was that the foreigners would introduce disease. ${ }^{46}$ This threat was particularly alarming because the disastrous cholera epidemic of 1892 that had claimed the lives of more than 8,000 victims in 1892 was still fresh in their memory. ${ }^{47}$

The warning of such imminent danger that threatened the whole city served three purposes. First, it portrayed the native Hamburg labourers as 'safer'-i.e. less dangerous than the foreigners - and it contributed to the aforementioned target of 'desecuritizing' the working class. Second, the warning against immigration had the target of mobilising those parts of the Hamburg population that were not directly concerned by the strike and thus rallying them to join their side. This seems to have been successful at least for a part of the petty bourgeoisie. ${ }^{48}$ Third, it allowed the strikers to call upon the Hamburg Senate for intervention. The social democratic newspaper Das Hamburger Echo, for example, wrote: "Indeed, the mass immigration of degenerated and ragged foreigners, who pose the greatest social and sanitary danger for the state of Hamburg, is a crime. It is the task and the duty of the police to prevent such crimes." 49 Whereas the question whether the state ought to intervene in labour conflicts was highly controversial among the contemporaries, the defence against epidemics belonged to the traditional and unquestioned functions of the state. And

45 E.g. Hamburger Neuigkeiten. Der Streik der Hafenarbeiter, in Das Hamburger Echo, 25 November 1896; Polizei-Offiziant Thomas, Bericht über Versammlung der Werftarbeiter 27 November 1896, Hamburger Staatsarchiv, 331-3/7095; Polizei-Offiziant Baumann, Bericht über die Mitglieder-Versammlung des Verbandes der Hafenarbeiter und Speicherarbeiter, 27 November 1896, Hamburger Staatsarchiv, 331-3/7095.

46 Die schwarze und gelbe Bemannung, in Das Hamburger Echo, 14 January 1897; cf. numerous reports about strikers' assemblies, Hamburger Staatsarchiv, 331-3/7095 and 331-3/7125.

47 Cf. Evans 1987, passim.

48 Zum Streik der Hafenarbeiter, in Hamburgischer Correspondent, 4 December 1896, Abend-Ausgabe, p. 3.

49 Hamburger Neuigkeiten, in Das Hamburger Echo, 29 November 1896. 
indeed the city government reacted to these appeals. The Senate ordered the inspection of the hygienic standards of the mass accommodation centres, in which the strike-breakers lived, and it spoke out against the immigration of Italian workers, but it took no further steps to stop the recruitment of foreigners during the strike. ${ }^{50}$

The alarmist warning of the allegedly dangerous immigrants also had side effects. The resentments against strike-breakers-Germans and foreigners alike- lasted a long time. It strengthened nationalist and xenophobic feelings among the Hamburg working class and among the petty bourgeoisie. This unintended consequence further illustrates the limited agency of the labour movement being unable to channel the securitization towards its actual goals.

\section{Security policies}

Although securitization referred to varying objects according to the different political camps, its main objective was usually to impel the state to action. For many contemporaries, the state's primary task was to guarantee security. As it remained highly controversial whether social questions belonged to the state's tasks and duties as well, it seemed a more effective strategy to define demands regarding social problems in terms of security. However, conservatives, liberal social reformers and the organized working classes all placed different expectations upon the state ranging from intensified policing to far-reaching social reforms.

While social reforms were slow and contested as a matter of principle, police action was immediate and customary, and the exercise of heightened police vigilance was normally the first statutory measure when social conflict threatened to escalate. As the raison d'être of the police was the safeguarding of domestic security, the fact that security was a prime value for the police forces in both cities is self-explanatory. However, the police's security policies in Hamburg differed considerably from those in London. The Hamburg police clearly regarded the labour movement as a danger to the city and took strong action against it. During the Hamburg dock strike, they suppressed picketing, blocked the free access to the har-

50 Hamburger Staatsarchiv, 331-3/7112; Morandi 2004, pp. 121-125. 
bour, and forbade street collections in favour of the strikers. ${ }^{51}$ The political division of the Hamburg police had kept its surveillance routines, which Bismarck's anti-socialist laws had established. As indicated, policemen in plain clothes regularly spied on workers' pubs and meetings, and they meticulously recorded the discussions they overheard. ${ }^{52}$ These actions helped the police, for instance, to detect the British trade unionist Tom Mann, who visited Hamburg in September 1896 to promote the International Federation of Ship, Dock and Riverside Workers founded shortly before. The police arrested him and forced him to travel back to England. ${ }^{53}$ The irritation this security measure provoked amongst the Hamburg dock workers was an important trigger for the strike that broke out only two months later. ${ }^{54}$ During that strike, Tom Mann secretly travelled again to Hamburg with the aim of convincing the dock workers to resume work, because the leaders of the International Federation feared that the walkout, taking place in the middle of winter, would have little prospect of success and would therefore weaken international trade unionism. Again, the Hamburg police detected and expelled Tom Mann. Examining his belongings, they found, alongside some moustache wax and toothpicks, a letter warning "that it would be a serious blow to the Int. Fed. if the Hamburg Dockers were defeated [...]. Whereas if the men [could] be induced to return to work, even on a small concession, it would be a victory and [would] lessen the danger of involving the Int. Fed. in the gulf." 55 Although Senator Georg Hachmann, the head of the police, admitted in a letter to the Hamburg mayor Johannes Versmann that he did not know whether there was a legal footing for an inspection of Mann's correspondence, the police confidentially sent a copy of this letter to the dock direc-

51 Bieber 1978, pp. 131-132.

52 Cf. Evans 1989 as well as Owzar 2006.

53 Hamburger Staatsarchiv, 331-1/7753.

54 Cf. Bieber 1978, pp. 111-112; already the strikers themselves were convinced of this effect of Tom Mann's arrestation and expulsion, cf. e.g. Polizei-Offiziant Grimmelshäuser, Bericht über die öffentliche Versammlung der Kohlenarbeiter, 24 November 1896.

55 Letter by Tom Chambers to Tom Mann, November 1896, Staatsarchiv Hamburg, 331-3/7095. 
tors' association. ${ }^{56}$ Consequently, the dock directors hardened their intransigent position and decided to outfight the strikers at all costs.

The Hamburg police was able to implement its restrictive security measures without taking into account the criticism of the working-class organizations, social democrats or social reformers. The London Metropolitan Police, by contrast, had a more limited scope for its security policy. The conflict between the Police Commissioner, Charles Warren, and the Home Secretary, Henry Matthews, in 1887, shows this clearly. Warren, who was appointed Commissioner of the London Metropolitan Police shortly after the West End Riots, wanted to show that the police had learnt a lesson from this failure. He was convinced that the mass demonstrations in 1887 were a "danger to the safety of the Metropolis" bound to end in a "catastrophe." Therefore, he advocated repressive measures against the protestors and was determined to dispel them from Trafalgar Square. ${ }^{57}$ Matthews, on the contrary, felt uneasy in this respect and commissioned various legal opinions to help him decide on the matter. Again and again he stopped Warren, insisting on the principle: "The Police must at all events keep within the law." 58 Warren eventually succeeded in convincing Matthews of the need to ban political manifestations from Trafalgar Square through legal quibbling. ${ }^{59}$ However, considerable parts of the London press heavily criticized the violent expulsion of protestors on 'Bloody Sunday,' which was exerted under his responsibility. During the London dock strike, one and a half years later, Warren's successor, ${ }^{60}$ James Monro, was anxious not to give way to the dock companies' peremptory demands to combat picketing. Like Matthews, Monro stressed that the police had to act "in accordance with, and within the limits of law" and to maintain "an

56 Letter by Gustav Roscher to Carl Ferdinand Laeisz, 26 November 1896; letter by Georg Hachmann to Johannes Versmann, 1 December 1896, Hamburg, 331-3/7095.

57 Letter by Charles Warren to Godfrey Lushington, 8 October 1887, The National Archives, HO 144/204/A47976/1TO70. Cf. for Warren's position and the conflicts between him and the Home Office Bailey 1981.

58 Letter by Henry Matthew to Charles Warren, 2 November 1887, The National Archives, HO 144/204/A47976/ 1TO70.

59 Letter by Charles Warren to Henry Matthews, 31 October 1887, The National Archives, HO 144/204/A47976/ 1TO70.

60 Warren resigned from office in November 1888 primarily because of his failure to catch Jack the Ripper, but also because of his discrepancies with the Home Office. 
attitude of the strictest impartiality." 61 And Monro, quite like Home Secretary Matthews, was not only concerned with law but also with the judgment of the public, as they believed the people would condemn police suppression of protestors or of strikers. ${ }^{62}$

Police measures in both cities seem to reflect the different degree of significance that the security issues played in the public discourse of both cities. However, it would be erroneous to equate the municipal government in Hamburg with the camp of confrontation depicted above or to believe that state action in London was inspired by social reform. Although in Britain the state was also in the process of slowly changing the definition of its traditional tasks, the immediate state reaction to the demonstrations of the unemployed and to the dock strike remained restricted to police and juridical measures. In Hamburg, however, the dock strike directly prompted the Senate to initiate several social reforms. Just after the end of the strike, the Hamburg Senate convened a "Commission zur Überprüfung der Arbeitsverhältnisse im Hafen" (Review Commission of the Working Conditions in the Harbor). ${ }^{63}$ Moreover, the city engaged a port inspector. In an internal report about the strike, the police department, although it had so decidedly taken side with the employers during the labour conflict, even proposed to the Senate to introduce permanent boards of conciliation and arbitration, but this suggestion was not yet carried out in the immediate future. ${ }^{64}$ However, all these initiatives aimed at the detection of grievances and at the prevention of future strikes. Although working-class leaders doubted the impartiality and effectiveness of the report and the inspector alike, ${ }^{65}$ these measures were important novelties showing that the

61 Letter by James Monro to Godfrey Lushington, 23 September 1889, The National Archives, H 144/227/A50732; Letter by James Monro to Henry Matthews, The National Archives, September 1889, MEPO 2/472.

62 Letter by Henry Matthews to Godfrey Lushington, The National Archives, HO 144/204/A47976/1TO70, 15 November 1887; letter by James Monro to C.M. Norwood, 19 September 1889, MEPO 2/226.

63 Cf. Protokolle der Senats-Commission für die Prüfung der Arbeitsverhältnisse im Hamburger Hafen über die Vernehmung von Arbeitgebern und Arbeitnehmern, Hamburg 1898; Bericht der Senats-Commission für die Prüfung der Arbeitsverhältnisse im Hamburger Hafen, Hamburg 1898.

64 Der Streik der Hamburger Hafenarbeiter 1896/97. Amtliche Darstellung nach den Akten der Abtheilung 2 (Politische und Criminal-Polizei) der Polizei-Behörde, Hamburg 1897, p. 115.

65 Hamburger Staatsarchiv, 331-1/7153; Carl Lindow: Die Verkehrs- und Arbeitsverhältnisse im Hamburger Hafen, Berlin 1915, pp. 209-210. 
municipal government assumed social responsibility and started to accept a mediating role in social conflict. This was, in a way, the flip side of the entrepreneurial success in securitizing working-class unrest. In order to avoid the Senate's commission, which-whatever its biases against working class interests - meant an intrusion into a space claimed as a sphere of entrepreneurial authority, desecuritization would have been a prerequisite - an option not available due to the earlier securitization.

However, the changing perception of the state's tasks cannot be explained solely by the willingness to resolve social conflict, let alone by the inclination to reduce power imbalances, but rather has to be seen in a wider context. There was a range of other factors that made urban poverty appear threatening and called for social reforms. The growing slums became a source of serious preoccupation as they were believed to be not only hotbeds of revolution, but also breeding grounds for immorality, criminality, and disease. In Hamburg, the cholera epidemic of 1892 nourished such perceptions, quite like in London with the murders committed by Jack the Ripper in $1888 .{ }^{66}$ Often, different concerns mingled, as can be seen, for example, in the development of an increasing state activity to enhance the housing conditions for the poor.

\section{Conclusion}

It is obvious that security discourses dominated politics and policy much more in Hamburg, where all political camps tried to use securitization as an instrument of power. Questioning the reasons for the varying degrees of effectiveness of securitization or desecuritization and also the different agency of the police in both cities, we have already mentioned that the political antagonism was seated more deeply and boundaries between social democracy and liberalism were much sharper in the German Empire than in Britain, where the labour movement was weaker but received more recognition by the middle class. Moreover, it was decisive that the understanding of the state fundamentally diverged in both cities. Securitization usually went along with an appeal to state action, either highlighting the necessity of police intervention or calling for new laws or for the creation of new statutory institutions as, for example, boards of arbitration. This

66 Cf. Walkowitz 2011; Evans 1987; as well as Lenger 2013, pp. 251-255. 
explains why the conflicting parties tried to use securitization more often in Hamburg than in London, where traditionally more distrust in state action prevailed. It also explains why the police was more reticent in the British metropolis.

If contemporaries used securitization with the primary aim to provoke the intervention of the state, i.e. to make statutory power work for their own goals, the effects were not restricted to this mechanism. Securitization also tended to exacerbate antagonism, be it between the working classes and the middle classes, between the camp of confrontation and the camp of social reform or between strikers and strike-breakers. Not least, due to this exacerbation of antagonism, the Hamburg entrepreneurs succeeded in strengthening their own position of power and in weakening the camp of social reform. Again, however, neither the Hamburg workers nor the London dock directors were able to use this mechanism for their own purposes, despite having tried to make use of it. Therefore, some of the strikers believed that the only effective instruments of power they had at hand were threats, intimidation and violence, but these were ambivalent and contested, as they could easily lead to repressive police reaction. Securitization, however, which as an instrument of power seemed less problematic in this respect, remained reserved for those groups who were acting from a position of strength and were able to use also "authoritative" and financial power to influence the public and the authorities.

\section{Epilogue}

While the conceptual apparatus of the Copenhagen School—if enlarged by the attention paid to audiences by Thierry Balzacq and others-has clearly demonstrated its usefulness in highlighting why a securitization of labour unrest did not take place in London and why the securitizing move of the dockworkers in Hamburg in the end proved unsuccessful, a comparative look at power relations in our two cities suggests the possibility of a different reading. ${ }^{67}$ However, contrary to authors like Didier Bigo or Jef Huysmans, we do not turn to security practices and technologies ("banal, little security nothings"). ${ }^{68}$ Instead we try to make use of the Foucauldian

67 Cf. Balzacq 2011.

68 Huysmans 2011, p. 371; Bigo 2002, esp. p. 73. 
notion of a liberal governmentality, a notion that has not featured prominently in urban history so far. ${ }^{69}$ In doing so, we are at least methodologically closer to Foucault's famous lectures on the history of governmentality held in 1978/79. As he put it himself, he was investigating "how the practice of police actually appeared in the texts," police to be understood here in the comprehensive early modern meaning of good government and administration. ${ }^{70}$ While there are obvious limits to this very specific variant of a history or genealogy of ideas, the arguments put forward are useful for our comparison if one keeps in mind that the liberalism in Foucault's concept of liberal governementality is not congruent with liberal positions in the two political arenas under scrutiny.

There is a certain ambivalence in Foucault's own use of the terms sovereignty, disciplinary power and governmental administration. Despite the author's explicit denial, they sometimes take on the character of a sequence of power techniques or of stages on which one of these power techniques is prevalent. Risking oversimplification, one could interpret late nineteenth-century London as a model of liberal governmentality. While "discipline, by definition, regulates everything," its liberalist counterpart leaves alone. ${ }^{71}$ As we will see, this does not imply a strict policy of non-intervention, but it does presuppose that economy and society are quasi-natural entities regulating themselves: "the population as a collection of subjects is replaced by the population as a set of natural phenomena." 72 This has at least two implications. The negative one is that the lack of insight into the mechanisms regulating society and economy on the part of the state makes state intervention potentially harmful. This risk may be lessened if the knowledge produced by economists and social scientists is taken into account whose new importance is, of course, the positive implication: "The laws and principles of political economy, the collected data and facts of statistical sciences and the knowledge provided by social science are part and parcel of governmentalisation." 73

69 The most important exception being Joyce 2003.

70 Foucault 2007, p. 333.

71 Id., p. 45.

72 Id., p. 352; for a good reconstruction of Foucaults position cf. the first chapter of Ronge 2015, pp. 33-118, or, more generally, Neocleous 2000, esp. chapters II and III.

73 Bohlender 2007, p. 253; cf. id., p. 106 (authors' translation). 
Now, while a naturalist understanding of population provides ample justification for a revalorisation of social science, it does not rule out any intervention in economic or social processes. On the most general level the liberal laissez-faire attitude produces the need of ,the protection of the collective interest against individual interests." Or, as Foucault puts it a little later: "The game of freedom and security is at the very heart of this new governmental reason." $" 74$ Matthias Bohlender has thoroughly investigated English liberal discourse of the eighteenth and nineteenth centuries and documents countless utterances rendering Foucault's assertion more concrete. Their common denominator is the conviction that the self-regulatory mechanisms of society and economics are in constant need of defense. This has occasionally quite surprising implications. The philosopher and economist Charles Babbage, for example, argued in 1832: "The principle, that government ought to interfere as little as possible between workmen and their employers, is so well established, that it is important to guard against its misapplication. It is not inconsistent with this principle to insist on the workmen being paid in money--for this is merely to protect them from being deceived; and still less is it a deviation from it to limit the number of hours during which children shall work in factories, or the age at which they shall commence that species of labour - for they are not free agents, nor are they capable of judging, if they were; and both policy and humanity concur in demanding for them some legislative protection. In both cases it is as right and politic to protect the weaker party from fraud or force, as it would be impolitic and unjust to interfere with the amount of the wages of either."75

Twelve years earlier the economist John R. McCulloch had similarly defended trade unions and strikes, arguing that employers would never increase wages voluntarily. Therefore, collective pressure would be the only way to find out whether wage demands would be fair and reasonableseemingly just another expression for being in accordance with supply and demand in the labour market. ${ }^{76}$ Accordingly, the Morning Post maintained on September 16, 1889: "We still retain the opinion that all dislocations in the relations between capital and labour are best left to adjust themselves."77 If documentation were needed that this was by no means a mi-

74 Foucault 2008, p. 65.

75 Babbage 1832, p. 363, paragraph 436 (cited from Bohlender 2007, p. 335).

76 Cited id., pp. $277 \mathrm{f}$.

77 Morning Post, 16th of September 1889, p. 4. 
nority position, it was provided a week later when the Times printed a speech by Gladstone in which he described the relationship between capital and labour as "a balance of force, [...] a fair adjustment between them, which must always determine in what degree the profits of industry ought to go and are to go to the man who works with his hands, and in what degree they are to go to the capitalist, who is supposed to bring, and generally does bring, as his contribution [...] the use of his brains and the use of the capital already saved." Accordingly the former and future premier welcomed the result of the strike "as a real social advance; that it tends to a greater, a more uniform, and a more firm establishment of just relations; that it tends to a fair principle of division of the fruits of industry." 78

These examples may suffice to bolster the point that at the time of the events described in the earlier parts of this article, principles of a liberal governmentality had been firmly established and deeply entrenched in the English case - a statement different from and completely independent of any judgement about the relative strength of liberal and conservative forces in the political arena. This makes it easier to understand why social reformers like Samuel Barnett, who invited striker leaders to a dinner celebrating their success, were not at all ostracized by other middle-class Londoners who might have been less favourably disposed towards the strikers. It also explains why the statistical material collected with the massive financial support of Charles Booth carried much more weight in the English debate than the ideas of social reformers like Tönnies and Herkner, who were easily sidelined within the Hamburg debate. Furthermore, it makes clear that liberal governmentality left little room for the securitization of labour disputes. Whether that holds true for social policy more generally seems doubtful, as we have seen with Babbage's arguments against the infamous truck system or in favour of protective regulations of child labour. These interventions were, however, meant to ensure the smooth and fair functioning of the self-regulatory mechanisms of economy and society, while the authoritarian paternalism prevalent in Hamburg showed much less reluctance to interfere with these mechanisms. ${ }^{79}$

There are occasional dissenting utterances in Hamburg, for example, a letter to the editor of the Hamburger Fremdenblatt whose author opined

78 Times, 24th of September 1889, p. 10.

79 It is beyond the scope of this article to discuss the changes within liberal governmentality needed to enable social policies as demanded by the Fabians and articulated e.g. by the Beveridge plan. 
"that the accomplishment of the demands put forward by the workers would not have shaken the capitalist order at all," but this was clearly a minority position. ${ }^{80}$ The opposite view was so dominant that the Hamburgischer Correspondent could declare it anachronistic to consider "the current strike as a merely internal affair of dockworkers and their employers." 81 In London by contrast, the lesson of the strike widely accepted was "that the working man of to-day thinks for himself and acts for himself. He needs instruction - not guardianship and patronage." 82 Such an antipaternalist position had little appeal for the middle class in Hamburg. Furthermore, it is hard to imagine a leading politician there or in any other German city to speak out against any restrictions of anarchist demonstrations by talking of "a handful of insignificant men who used, no doubt, foolish and violent language on Sunday afternoon in Trafalgar Square, but who [...] have not committed any offence against the law," as the later premier Asquith did in $1893 .{ }^{83}$

\section{References}

Babbage, Charles (1832): On the Economy of Machinery and Manufactures. Third edition. London: Charles Knight.

Balzacq, Thierry (2011): A theory of securitization: origins, core assumptions, and variants, in: Thierry Balzacq (ed.): Securitization Theory: How Security Problems Emerge and Dissolve. London/New York: Routledge, pp. 1-30.

Bantman, Constance (2014): Anarchists, authorities and the battle for public space, 1880-1914: Recasting political protest as anti-social behavior. In: Sarah Pickard (ed.): Anti-Social Behaviour in Britain. Victorian and Contemporary Perspectives. Houndmills: Palgrave Macmillan, pp. 65-76.

Bailey, Victor (1981): The Metropolitan Police, the Home Office and the threat of outcast London. In: Victor Bailey (ed.): Policing and Punishment in Nineteenth-Century Britain. London: Croom Helm, pp. 95-124.

Bieber, Hans-Joachim (1978): Der Streik der Hamburger Hafenarbeiter 1896/97 und die Haltung des Senats. Zeitschrift des Vereins für Hamburgische Geschichte 64: 91-148.

Bigo, Didier (2002): Security and immigration: toward a critique of the governmentality of unease. Alternatives: Global, Local, Political 27(1): 63-92.

80 Hamburger Fremdenblatt, 9th of December 1896.

81 Hamburgischer Correspondent, 9th of December 1896, p. 17.

82 Reynolds News, 22nd of September 1889, 1.

83 Cited in Bantman 2014, p. 73. 
Bohlender, Matthias (2007): Metamorphosen des liberalen Regierungsdenkens. Politische Ökonomie, Polizei und Pauperismus. Weilerswist: Velbrück.

Booth, Charles (1902f.): Life and Labour of the People of London. 17 volumes. London: Macmillan \& Co.

Briggs, Asa/Macarntey, Ann (1984): Toynbee Hall. The First Hundred Years. London: Routledge/Kegan Paul.

vom Bruch, Rüdiger (1981): Streiks und Konfliktregelung im Urteil bürgerlicher Sozialreformer 1872-1914. In: Klaus Tenfelde/Heinrich Volkmann (eds): Streik. Zur Geschichte des Arbeitskampfes in Deutschland während der Industrialisierung. München: Beck, pp. 253-270.

C.A.S.E. Collective (2006): Critical approaches to security in Europe: A network manifesto. Security Dialogue 37(4): 443-487.

Evans, Richard J. (1987): Death in Hamburg. Society and Politics in the Cholera Years. Oxford: Oxford University Press.

Evans, Richard J. (1989): Einleitung. In: Richard J. Evans (ed.): Kneipengespräche im Kaiserreich. Die Stimmungsberichte der Hamburger Politischen Polizei, 1892-1914. Reinbek b.H.: Rowohlt, pp. 7-39.

Foucault, Michel (2007): Security, Territory, Population: Lectures at the Collège de France 1977-1978. New York: Picador/Palgrave Macmillan.

Foucault, Michel (2008): The Birth of Biopolitics: Lectures at the Collège de France 1978-1979. New York: Picador/Palgrave Macmillan.

Grüttner, Michael (1984): Arbeitswelt an der Wasserkante: Sozialgeschichte der Hamburger Hafenarbeiter 1886-1914. Göttingen: Vandenhoeck \& Ruprecht.

Hansen, Lene (2012): Reconstructing desecuritisation: the normative-political in the Copenhagen School and directions for how to apply it. Review of International Studies 38: 525-546.

Herkner, Heinrich (1924): Heinrich Herkner, in: Felix Meiner (ed.): Die Volkswirtschaftslehre der Gegenwart in Selbstdarstellungen. Leipzig: F. Meiner, pp. 77-116.

Huysmans, Jef (2011): What's in an act? On security speech acts and little security nothings, Security Dialogue 42(4-5): 371-383.

Joyce, Patrick (2003): The Rule of Freedom: Liberalism and the Modern City. London: Verso.

Keller, Lisa (2008): Triumph of Order: Democracy and Public Space in New York and London. London/New York: Columbia University Press.

Lenger, Friedrich (2013): Metropolen der Moderne. Eine europäische Stadtgeschichte seit 1850. München: Beck.

Lindenberger, Thomas (1993): "Streikexzesse“. Zum Sinn und Eigen-Sinn direkter Straßen-Aktionen bei Arbeitskämpfen in Berlin, 1900 bis 1914. Zeitschrift für Sozialgeschichte des 20. und 21. Jahrhunderts 8(2): 51-69.

McCarthy, Terry (1988): The Great Dock Strike 1889. London: Weidenfeld \& Nicolson.

Meacham, Standish (1987): Toynbee Hall and social reform 1880-1914. The Search for Community. New Haven, Conn.: Yale University Press. 
Morandi, Elia (2004): Italiener in Hamburg. Migration, Arbeit und Alltagseben vom Kaiserriech bis zur Gegenwart. Frankfurt a.M.: Peter Lang.

Neocleous, Mark (2000): The Fabrication of Social Order. A Critical Theory of Police Power. London: Pluto Press.

Opitz, Sven (2008): Zwischen Sicherheitsdispositiven und Securitization: Zur Analytik illiberaler Gouvernementalität. In: Patricia Purtschert/Katrin Meyer/Yves Winter (eds.), Gouvernementalität und Sicherheit. Zeitdiagnostische Diagnosen im Anschluss an Foucault, Bielefeld, pp. 201-228.

Owzar, Armin (2006): , Reden ist Silber, Schweigen ist Gold'. Konfliktmanagement im Alltag des wilhelminischen Obrigkeitsstaates. Konstanz: UVK.

Reulecke, Jürgen (1981): Sozialer Konflikt und bürgerliche Sozialreform in der Frühindustrialisierung. In: Klaus Tenfelde/Heinrich Volkmann (eds): Streik. Zur Geschichte des Arbeitskampfes in Deutschland während der Industrialisierung. München: Beck, pp. 237-252.

Ronge, Bastian (2015): Das Adam-Smith-Projekt. Zur Genealogie der liberalen Gouvernementalität. Wiesbaden: Springer.

Tönnies, Ferdinand (2010a): Die Enquête über die Zustände der Arbeit im Hamburger Hafen, in: Schriften zum Hamburger Hafenarbeiterstreik. Ed. by Rolf Ferchner. München: Profil, pp. 169-224.

Tönnies, Ferdinand (2010b): Der Hamburger Strike von 1896/97, in Schriften zum Hamburger Hafenarbeiterstreik. Ed. by Rolf Ferchner. München: Profil, pp. 100157.

Tönnies, Ferdinand/Paulsen, Friedrich (1961): Briefwechsel 1876-1908. Ed. by Olaf Klose et al. Kiel: Hirt.

Walkowitz, Judith (2011): City of Dreadful Delight: Narratives of Sexual Danger in Late-Victorian London. Chicago: University of Chicago Press.

Wasp, David/Davis, Alan (1974): The Great Dock Strike, 1889. London: Longman.

Wæver, Ole (1995): Securitization and Desecuritization. In: Ronnie Lipschutz (ed.): On Security. New York: Columbia University Press, pp. 46-86. 
